\title{
Performance, carcass and meat characteristics of two cattle categories finished on pasture during the dry season with supplementation in different forage allowance
}

[Desempenho, características da carcaça e carne de duas categorias de bovinos de corte terminados em pastagem durante a estação seca com suplementação em diferentes ofertas de forragem]

\author{
A.S. Aranha ${ }^{1}$, C. Andrighetto ${ }^{2 *}$, G.C. Lupatini ${ }^{2}$, G.P. Mateus ${ }^{3}$, C. Ducatti ${ }^{4}$, R.O. Roça ${ }^{4}$, M.B. Martins ${ }^{1}$, \\ J.A.A. Santos ${ }^{5}$, P.A.C. Luz $^{2}$, A.T.H. Utsunomiya ${ }^{6}$, N.B. Athayde ${ }^{7}$ \\ ${ }^{1}$ Aluno de pós-graduação da Universidade Estadual Paulista - Botucatu, SP \\ ${ }^{2}$ Universidade Estadual Paulista - Dracena, SP \\ ${ }^{3}$ Agência Paulista de Tecnologia dos Agronegócios - Andradina, SP \\ ${ }^{4}$ Universidade Estadual Paulista - Botucatu, SP \\ ${ }^{5}$ Aluno de pós-graduação - Universidade de São Paulo - Piracicaba, SP \\ ${ }^{6}$ Aluno de pós-graduação - Universidade Estadual Paulista - Araçatuba, SP \\ ${ }^{7}$ Empresa Brasileira de Pesquisa Agropecuária - Embrapa - Rio Branco, AC
}

\begin{abstract}
The objective this paper was to evaluate the effect of two categories of beef finished in pasture with supplementation with two herbage allowance on performance, carcass and meat characteristics. Thirty-six Guzera cattle were used, 18 steers and 18 heifers with an initial age of 20 months. There was significant difference in daily weight gain for animal category and the herbage allowance, which were higher in males and animals submitted to high herbage allowance. Steers showed higher final weight, carcass weight and forequarter yield compared with the heifers, although the hindquarter yield was higher in the heifers, however the herbage allowance did not influence these characteristics. There were not statistical differences for carcass yield, ribeye area, backfat thickness and marbling score for the animal categories and herbage allowance. The meat chemical composition of the steers did not differ of the heifers, however, the animals submitted to high herbage allowance was increase in ether extract and $\mathrm{pH}$, decrease in protein percentage. It was concluded that the animal category and the herbage allowance changed the animal performance, improving performance in males and cattle submitted to high herbage allowance.
\end{abstract}

Keywords: animal supplementation, meat quality, weight gain

\section{RESUMO}

O objetivo do presente trabalho foi avaliar o efeito de duas categorias de bovinos terminados em pastagem com suplementação em duas ofertas de forragem no desempenho, na qualidade da carcaça e da carne. Foram utilizados 36 bovinos Guzerá, 18 novilhos e 18 novilhas, com idade inicial de 20 meses de idade. Observou-se diferença significativa no ganho de peso diário para categoria animal e ofertas de forragem, que foram superiores nos machos e nos animais submetidos à oferta alta de forragem. Os novilhos apresentaram maior peso final, peso de carcaça e rendimento de dianteiro em comparação com as novilhas, embora o rendimento do traseiro tenha sido maior para as novilhas, entretanto as ofertas de forragem não influenciaram essas características. Não houve diferenças estatísticas para rendimento de carcaça, área de olho de lombo, espessura de gordura subcutânea e marmorização para categorias de animais e ofertas de forragem. Quanto à composição química, a carne de novilhos não diferiu das novilhas. Os animais submetidos à alta oferta de forragem tiveram aumento no extrato etéreo e pH, redução na porcentagem de proteína. Conclui-se que a categoria animal e os níveis de forragem alteram o desempenho animal, melhorando, assim, o desempenho nos machos e nos bovinos submetidos à alta oferta de forragem.

Palavras-chave: ganho de peso, qualidade da carne, suplementação animal

Recebido em 10 de novembro de 2016

Aceito em 31 de maio de 2017

*Autor para correspondência (corresponding author)

E-mail: cristiana@dracena.unesp.br 


\section{INTRODUCTION}

According to the Anuário (2016), approximately $84 \%$ of the total number of cattle slaughtered in Brazil in 2015 was finished in pastures and other animals $(16 \%)$ were finished in feedlot systems or semi-feedlot. Brazil has favorable climatic characteristics during the summer for production of tropical forages, and consequently, has suitable conditions for beef cattle production on grasslands. (Barbero et al., 2017).

The seasonal production of forage is the principal factor responsible for the low national livestock productivity, reducing the forage production in periods when decreased photoperiod, average temperature, and rainfall. These three factors together decrease the forage grow throughout the year, resulting decrease in quantitative and qualitative forage availability, affecting performance and meat quality of animals kept on pasture (Reis et al., 2006).

Under these conditions, especially during the dry period, limit the growth of forages require strategies, such as the use of supplementation (Barbero et al., 2017). The supplementation is alternative to accelerate weight gain and increase the use of available forage resources (Euclides et al., 2009).

However, for the effectiveness of supplementation the forage availability is important, since this takes priority over the stocking rate, so that similar stocking rates may result in differences in animal performance (Sollenberger et al., 2005).

In the literature, there are many papers with supplementation during the dry period related to the performance, carcass, and meat quality characteristics (Euclides et al, 2009, Garcia et al., 2014, Barbero, et al., 2017), however, there is little information using different herbage allowance. In addition, the majority of the papers are with males and the evaluation of supplementation in different animal categories also deserves attention. Heifers, when not used for the replacement of the herd, were finished for beef production and the meat is sold in significant quantities to the consumer.

Therefore, the objective of the study is to evaluate the effects of supplementation in beef cattle categories (steers and heifers) finished in pasture during the dry season and submitted two herbage allowance (high and medium) on performance, carcass traits and meat quality.

\section{MATERIALS AND METHODS}

The experiment was conducted in Agência Paulista de Tecnologia dos Agronegócios Andradina, SP. The predominant climate in the region is the Aw, according Koppen, the annual precipitation of the region is around $1,257 \mathrm{~mm}$, concentrating $78 \%$ of the rains in October-April and $22 \%$ May-September, characterizing the dry season.

Thirty-six Guzera cattle with initial age of 20 months, were divided into 18 heifers and 18 steers in growing and finishing stages, with average initial weight of $370 \mathrm{~kg}$ and $330 \mathrm{~kg}$ for steers and heifers, respectively. The experiment was carried in accordance with the ethical principles for animal experimentation (Protocol 35/2011) determined by the Ethics Committee on Animal Use of the.

The design was a randomized block with three replicates (paddock) in a $2 \times 2$ factorial, with two categories of beef cattle (steers and heifers) and two herbage allowance (average of $7 \mathrm{~kg}$ DM 100 ${ }^{1} \mathrm{~kg} \mathrm{BW}$ and high, with $13 \mathrm{~kg} \mathrm{DM} 100^{-1} \mathrm{~kg} \mathrm{BW}$ ), distributed in four treatments. The experiment was 3 animals for paddock, totaling 9 animals per treatment. The paddocks size were $1,7 \mathrm{ha}$.

The experimental period was 140 days $(08 / 07$ to $25 / 11 / 2011$ ), divided into five periods of 28 days. The percentage of concentrated supplement ingredients provided for animals was $48.8 \%$ soybean hulls, $30.2 \%$ citrus pulp, $17 \%$ soybean meal, $2.0 \%$ mineral supplement and 2\% urea (percentages are expressed on dry matter) with $22 \%$ crude protein and $74.5 \%$ total digestible nutrients. The nutritive value analyzes of the forage were evaluated for grazing simulation, every 28 days, according to the method proposed by Sollenberger and Cherney (1995). The determination of the neutral detergent fiber (NDF) and the acid detergent fiber (ADF) was followed the methodology proposed for Van Soest (1994) and crude protein according (CP) Silva and Queiroz et al. (2002). The average values in the experimental period of NDF were 71.79 and $70.30 \%$, and FDA 33.83 and 32.51, 
respectively, for medium and high herbage allowance.

The percentage of crude protein of the forage in the experimental period was $5.9 \%$ and the supplement was calculated to supplied the expected performance of $0.7 \mathrm{~kg} / \mathrm{day}$, based on supplementation of $0.8 \%$ of body weight. Diets were formulated by Supercrac 4.7 for beef cattle and based on the Nutrient (1996). The adaption period of the animal was two weeks for the supplement, initially receiving $1.5 \mathrm{~kg}$ of concentrate per animal, increasing it gradually until reaching $0.8 \%$ of body weight. The supplements were provided daily between 11a.m. and 1p.m., trying not to change the behavior and grazing cycles. The supplement intake was restricted according to the animal weight, adjusted every 28 days after weighing.

The grazing method was the continuous stocking with stocking rate adjustment to maintain the herbage allowance required in each experimental unit. The pasture used was Urochloa brizantha cv. Marandu and the dry mass of average total forage recorded during the experimental period was 4,278 and $5,207 \mathrm{~kg} \mathrm{DM} / \mathrm{ha}$ for medium and high herbage allowance, respectively.

The average daily weight gain was calculated by the difference between the initial and final weights divided by the number of experiment days. At the end of the experiment, the animals were slaughtered at a commercial slaughterhouse after solid fasting (16 hours). At slaughter, carcasses were identified, weighed and refrigerated for 24 hours at a temperature of $0^{\circ} \mathrm{C}$. After 24 hours, the carcass was weighed and the carcass dressing, hindquarter, and forequarter yields were calculated.

Samples were collected from the Longissimus thoracis muscle for subsequent laboratory analysis. The determinations of ribeye area, fat thickness and marbling score were measured between the $12^{\text {th }}$ and $13^{\text {th }}$ ribs, after cooling the carcass according to the methodology described by United (Official..., 1997).
The meat color was determined in Longissimus thoracis muscle between the $12^{\text {th }}$ and $13^{\text {th }}$ ribs, by reading at three different points in muscle using the Minolta colorimeter CR- 400 Chroma Meter model. The CIELAB system has been considered, according to the methodology described by Honikel (1998).

The shear force was evaluated in the Longissimus thoracis muscle between the $12^{\text {th }}$ and $13^{\text {th }}$ ribs and the assessment was done by a texturometer TAXT - Plus Texture Analyser 2i, equipped with Warner-Bratzler device. The device descent speed was $20 \mathrm{~cm} / \mathrm{min}$ (Research..., 1995). The analyzes of shear force and color were made in the laboratory of the Department of Economics, Sociology and Technology (DEST), Faculty of Agricultural Sciences of the São Paulo State University "Julio de Mesquita Filho" (UNESP), Campus of Botucatu/SP.

The chemical composition, was used the Longissimus thoracis muscle between $11^{\text {th }}$ to $12^{\text {th }}$ ribs; the analysis was conducted in analyzes was: moisture, protein, ether extract and ash, according to the method recommended by the Association (Official..., 1990). The meat $\mathrm{pH}$ was determined in the Longissimus thoracis muscle, between the $11^{\text {th }}$ and $12^{\text {th }}$ ribs, after 24 hours of cooling.

The data were analyzed using the software SAS 9.2 (2008) for the analysis of variance (F test). Because interactions (categories $\mathrm{x}$ herbage allowance) were not detected, the results are reported as least square means and according to categories and herbage allowance. Differences were considered significant if $\mathrm{P}<0.05$.

\section{RESULTS}

The performance parameters and carcass traits are shown in Tab. 1, interaction between the animal category and herbage allowance was not found $(\mathrm{P}>0.05)$, thus the results were presented separately and demonstrating that the categories studied did not show differences in these parameters for different forage levels. 
Table 1. Performance and carcass traits of two cattle categories finished on pasture during the dry season supplementation in different herbage allowance

\begin{tabular}{|c|c|c|c|c|c|c|}
\hline \multirow{2}{*}{ Item } & \multicolumn{3}{|c|}{ Category } & \multicolumn{3}{|c|}{ Herbage allowance } \\
\hline & Steers & Heifers & $\mathrm{CV}^{3}(\%)$ & Medium & High & $\mathrm{CV}^{3}(\%)$ \\
\hline Final Weight (kg) & $450.8^{\mathrm{A}}$ & $382.7^{\mathrm{B}}$ & 3.71 & $408.7^{\mathrm{A}}$ & $424.8^{\mathrm{A}}$ & 9.32 \\
\hline $\mathrm{ADG}^{1}$ (g/day) & $649.0^{\mathrm{A}}$ & $476.0^{\mathrm{B}}$ & 18.02 & $510.0^{\mathrm{B}}$ & $615.0^{\mathrm{A}}$ & 22.51 \\
\hline $\mathrm{HCW}(\%)^{2}$ & $244.5^{\mathrm{A}}$ & $205.3^{\mathrm{B}}$ & 4.56 & $220.5^{\mathrm{A}}$ & $229.3^{\mathrm{A}}$ & 10.34 \\
\hline Carcass yield (\%) & $53.3^{\mathrm{A}}$ & $52.8^{\mathrm{A}}$ & 1.82 & $53.2^{\mathrm{A}}$ & $52.9^{\mathrm{A}}$ & 1.88 \\
\hline Hindquarter yield (\%) & $60.5^{\mathrm{A}}$ & $62.0^{\mathrm{B}}$ & 1.14 & $61.1^{\mathrm{A}}$ & $61.3^{\mathrm{A}}$ & 1.82 \\
\hline Forequarter yield (\%) & $39.5^{\mathrm{B}}$ & $37.9^{\mathrm{A}}$ & 1.80 & $38.8^{\mathrm{A}}$ & $38.6^{\mathrm{A}}$ & 2.87 \\
\hline Ribeye area $\left(\mathrm{cm}^{2}\right)$ & $65.7^{\mathrm{A}}$ & $59.6^{\mathrm{A}}$ & 9.02 & $64.0^{\mathrm{A}}$ & $61.3^{\mathrm{A}}$ & 10.24 \\
\hline Backfat thickness (mm) & $4.1^{\mathrm{A}}$ & $3.8^{\mathrm{A}}$ & 40.76 & $3.7^{\mathrm{A}}$ & $4.1^{\mathrm{A}}$ & 40.65 \\
\hline Marbling Score & $2.5^{\mathrm{A}}$ & $2.0^{\mathrm{A}}$ & 17.21 & $2.2^{\mathrm{A}}$ & $2.3^{\mathrm{A}}$ & 20.69 \\
\hline
\end{tabular}

Regarding animal categories, the steers had higher final weight, daily weight gain, hot carcass weight and forequarter yield compared to heifers $(\mathrm{P}<0.05)$. Only the hindquarter yield was higher in heifers compared to steers $(\mathrm{P}<0.05)$. No significant differences were observed in carcass yield, ribeye area, and backfat thickness between animal categories $(\mathrm{P}>0.05)$. There was a statistical difference for the average daily gain and animals subjected to high level had higher mean values compared with animals of the medium level $(\mathrm{P}<0.05)$ regarding herbage allowance.

There was no interaction between the animal category and herbage allowance for the meat quality parameters $(\mathrm{P}>0.05)$ and the data were shown separately in Tab. 2 and 3.

Table 2. Chemical composition of Longissimus thoracis muscle of two cattle categories finished on pasture during the dry season with supplementation in different herbage allowance

\begin{tabular}{ccccccc}
\hline \multirow{2}{*}{ Item } & \multicolumn{3}{c}{ Category } & \multicolumn{3}{c}{ Herbage allowance } \\
\cline { 2 - 7 } & Steers & Heifers & $\mathrm{CV}^{1}(\%)$ & Medium & High & $\mathrm{CV}^{1}(\%)$ \\
\hline Moisture (\%) & $74.30^{\mathrm{A}}$ & $75.15^{\mathrm{A}}$ & 1.06 & $74.41^{\mathrm{A}}$ & $75.04^{\mathrm{A}}$ & 1.14 \\
Protein (\%) & $24.06^{\mathrm{A}}$ & $23.04^{\mathrm{A}}$ & 6.28 & $24.67^{\mathrm{A}}$ & $22.44^{\mathrm{B}}$ & 4.26 \\
Ether extract (\%) & $1.82^{\mathrm{A}}$ & $1.50^{\mathrm{A}}$ & 19.28 & $1.46^{\mathrm{B}}$ & $1.86^{\mathrm{A}}$ & 17.59 \\
Ash (\%) & $1.16^{\mathrm{A}}$ & $1.15^{\mathrm{A}}$ & 1.92 & $1.15^{\mathrm{A}}$ & $1.15^{\mathrm{A}}$ & 1.97 \\
\hline
\end{tabular}

${ }^{1} \mathrm{CV}=$ Coefficient of variation.

${ }^{\mathrm{A}, \mathrm{B}}$ Least square means in the same row with superscripts differ at $\mathrm{P}<0.05$.

No significant differences were observed between meat chemical composition in different animal categories $(\mathrm{P}>0,05)$. The meat of animals submitted to the medium herbage allowance showed greater protein and ether extract percentage compared to animals on high herbage allowance $(\mathrm{P}<0.05)$. The moisture and ash content of the meat did not differ between the allowance ( $\mathrm{P}>0.05)$ (Tab. 2). 
Table 3. Shear force, cooking loss, $\mathrm{pH}$ and color of Longissimus thoracis muscle of two cattle categories finished on pasture with supplementation during the dry season in different herbage allowance

\begin{tabular}{ccccccc}
\multirow{2}{*}{ Item } & \multicolumn{3}{c}{ Category } & \multicolumn{3}{c}{ Herbage allowance } \\
\cline { 2 - 7 } & Steers & Heifers & $\mathrm{CV}^{3}(\%)$ & Medium & High & $\mathrm{CV}^{3}(\%)$ \\
\hline WBSF $^{1}(\mathrm{kgf})$ & $5.68^{\mathrm{A}}$ & $6.50^{\mathrm{A}}$ & 15.87 & $6.03^{\mathrm{A}}$ & $6.16^{\mathrm{A}}$ & 17.48 \\
Cooking loss $(\mathrm{g})$ & $20.32^{\mathrm{A}}$ & $21.85^{\mathrm{A}}$ & 12.22 & $20.86^{\mathrm{A}}$ & $21.30^{\mathrm{A}}$ & 12.80 \\
$\mathrm{pH}$ & $5.76^{\mathrm{A}}$ & $5.71^{\mathrm{A}}$ & 2.22 & $5.65^{\mathrm{B}}$ & $5.82^{\mathrm{A}}$ & 1.14 \\
$L^{* 2}$ & $35.15^{\mathrm{A}}$ & $34.06^{\mathrm{A}}$ & 6.40 & $34.26^{\mathrm{A}}$ & $34.96^{\mathrm{A}}$ & 6.54 \\
$a^{*^{2}}$ & $19.08^{\mathrm{A}}$ & $18.03^{\mathrm{A}}$ & 8.73 & $18.59^{\mathrm{A}}$ & $18.51^{\mathrm{A}}$ & 9.26 \\
$b^{* 2}$ & $8.72^{\mathrm{A}}$ & $8.26^{\mathrm{A}}$ & 14.17 & $8.45^{\mathrm{A}}$ & $8.53^{\mathrm{A}}$ & 14.47 \\
\hline
\end{tabular}

${ }^{1} \mathrm{WBSF}=$ Warner-Bratzler shear force.

${ }^{2} L^{*}=$ Lightness; $a^{*}=$ Redness; $b^{*}=$ Yellowness

${ }^{3} \mathrm{CV}=$ Coefficient of variation.

${ }^{\mathrm{A}, \mathrm{B}}$ Least square means in the same row with superscripts differ at $\mathrm{P}<0.05$.

The shear force parameters, cooking loss, $\mathrm{pH}$ and color of the meat measured by for $\mathrm{a}^{*}, \mathrm{~b}^{*}$ and $\mathrm{L}^{*}$ were not different between the animal categories $(\mathrm{P}>0.05)$. In the herbage allowance, the meat $\mathrm{pH}$ of animals in high herbage allowance were higher compared to medium allowance $(\mathrm{P}<0.05)$. For the other parameters of meat quality, no significant differences between the two herbage allowances were observed $(\mathrm{P}>0.05)$, as shown in Tab. 3.

\section{DISCUSSION}

Performance data shows that the heifers had lower final weight compared to steers, this fact occurred due the lower initial weight and less weight gain in that category which also resulted in lower hot carcass weight. The low weight gain can be justified because heifers reach maturity earlier (in weight and age) decreasing muscle growth and favoring fat deposition earlier than steers, making this category less efficient in weight gain (Berg and Butterfield, 1976). The lower performance of heifers compared to steers was also evidenced by Vaz et al. (2010) that evaluated these two categories of cattle with initial average weight of 184.8 and $183.2 \mathrm{~kg}$, respectively, and observed differences in final weight $(365.8 \mathrm{~kg}$ in steers and $310.3 \mathrm{~kg}$ in heifers) and hot carcass weight $(203.4 \mathrm{~kg}$ in steers and $168.6 \mathrm{~kg}$ in heifers), fact explained by Di Marco (1993) as a reflection of higher growth caused by androgenic hormones, principally testosterone, present in high amount in males. Although the steers of this study have been castrated, there is yet production of testosterone by the adrenal glands, which were possibly responsible for higher performance in this category.

Regarding the forage levels, the animals exhibit greater weight when subjected to high level, showing that the weight gain of the animals supplemented with concentrates during the dry period is directly related to the amount of herbage allowance provided. The high forage supply increased the weight gain due to the greater forage mass, which allowed increase in the consumption and better selectivity of the forage consumed, furthermore the lower levels of NDF and ADF (71.79 and 70.30\%, and ADF 33.83 and 32.51 , respectively, for medium and high herbage allowance) and superior crude protein $(6.04 \%$ e $5.76 \%$, respectively for medium and high herbage allowance), resulting in higher nutrient consumption. According Bortolo et al. (2001) that the herbage allowance affects directly the energy consumption, which can affect performance. This statement was proven in this study where in animals submitted to the high herbage allowance consumed more, being this fact evidenced by higher average daily gain.

Regarding carcass characteristics, the steers had higher hot carcass weight and forequarter yield compared to the heifers. However, the hindquarter yield was lower, possibly due these 
animals were castrated with approximately 19 months old, which favored the sexual dimorphism and the muscle hypertrophy of forequarter and consequently the higher forequarter yield and lower hindquarter. The carcass yield, ribeye area, backfat thickness and marbling score did not differ between animal categories and between herbage allowances.

Regarding the carcass yield, the data were similar when comparing previous literature with animals subjected to the same conditions, $53.7 \%$ found by Barbero et al. (2017), respectively. The ribeye area can be used as an indicator trait of carcass composition associated with muscularity and yield of high value-added cuts (Baldassini et al., 2017). Borges et al. (2014) observed ribeye area of $65.62 \mathrm{~cm}^{2}$, in Nelore cattle similar value to the results obtained in this paper.

Carcasses with adequate backfat thickness decrease the effects of the cold shortening caused by cooling, which reduced meat tenderness (Felício, 1998). The animals of the present study had adequate back fat thickness to avoid the cold shortening (Tab. 1). Intramuscular fat was classified with marbling traces and this low score is related to the breed used, Zebu animals usually have meat with low marbling compared with British breeds.

On the chemical composition analysis of steers meat and heifers significant differences were not observed in moisture, protein, ether extract and ash. However, in herbage allowance, protein and lipid contents were different, the medium level showed higher protein content and lower lipids content and the high level resulted in a higher lipids content and lower protein content. This lower protein percentage in Longissimus thoracis muscle can be explained by the greater availability of forage in this treatment and consequently greater energy density of diet, which favored the greater deposition of fat, reducing the protein content. However, the amount of protein observed in the study is in agreement with Fidelis et al. (2017) that found values of the $23,5 \%$ in Nellore bulls.

The parameters that evaluated for meat quality characteristics were not different between categories and between herbage allowances, except the $\mathrm{pH}$ of Longissimus thoracis muscle from animals subjected to high herbage allowance level, which were lower than medium level. Therefore, the results of this study are according to regulations of the European Union, Circular No. 192 (Brasil, 1998), in which that carcasses with $\mathrm{pH}$ above 5.9 should be disqualified for export, therefore, the values found are within the $\mathrm{pH}$ required for export.

Rodas-Gonzalez et al. (2009) affirmed that for customer panelists, steaks with a WarnerBratzler shear values less than $4.09 \mathrm{kgf}$ would produce a customer satisfaction as high as $81 \%$. This suggests that $4.09 \mathrm{kgf}$ can be considered as the tenderness threshold (segregate tough to tender) thus, the animals of this paper had meat with shear force above the recommended by the author, which can be explained due the cattle was finished on pasture. Robinson et al. (2001), reported that pasture finished cattle has less tender than feedlot finished cattle. Another factor that may be related to shear force values is marbling, according to $\mathrm{Li}$ et al. (2006), is that high values of marbling reduce the cooking loss, inhibit shortening of muscle fibers, increasing the softness of meat. In this context, the greater shear force and high cooking loss content this study are also due to little marbling present in the meat.

Muchenjea et al. (2009) in a review about meat color, described that in beef, the average of lightness vary from 33.2 to 41.0 , the average $\mathrm{a}^{*}$ is between 11.1 to 23.6 and the average $b^{*}$ is between 6.1 and 11.3. Thus, the average values for the meat color into the treatments of this study were within the standards proposed by Muchenjea et al. (2009) and suitable for human intake.

\section{CONCLUSION}

Animal categories and herbage allowance influence animal performance, males showed higher performance. Thus, this category showed the highest weight of hot carcass, but the meat characteristics did not change, except for proteins, ether extract and $\mathrm{pH}$. The animals submitted to high herbage allowance, which showed decrease in protein content and increase of ether extract and $\mathrm{pH}$. However, for all parameters, the meat of these animals may be considered suitable for consumers. 


\section{ACKNOWLEDGMENTS}

This work was supported by FAPESP Foundation for Aid to Research of the State of São Paulo.

\section{REFERENCES}

ANUÁRIO da pecuária brasileira. 21.ed. São Paulo: FNP, 2016. p.376.

BALDASSINI, W.A.; CAHDULO, L.A.L.; SILVA, J.A.V et al. Meat quality traits of Nellore bulls according to different degrees of backfat thickness: a multivariate approach. Anim. Prod. Sci., v.57, p.363-370, 2017.

BARBERO, R.P.; MALHEIROS, E.B.; NAVE, R.L.G. et al. Influence of post-weaning management system during the finishing phase on grasslands or feedlot on aiming to improvement of the beef cattle production. Agric. Syst., v.15, p.323-331, 2017.

BERG, R.T.; BUTTERFIELD, R.M. New concepts of cattle growth. Sydney: University Press, 1976. 225p.

BORGES, B.O.; CURI, R.A.; BALDI, F. et al. Polymorphisms in candidate genes and their association with carcass traits and meat quality in Nellore cattle. Pesqui. Agropecu. Bras. v.49, p.364-371, 2014.

BORTOLO, M.; CECATO, U.C.; MARTINS, E.N. et al. Avaliação de uma pastagem de coastcross-1 (Cynodondactylon, Pers) sob diferentes níveis de matéria seca residual. Rev. Bras. Zootec. v.30, p.627-635, 2001.

BRASIL. Exportação de carne bovina brasileira para a União Europeia. Instrução relativa ao controle sistemático da obtenção até a expedição e a preservação da origem destacada no rótulo do produto final colocado no mercado Comunitário. Circular no 192. Diário Oficial da União. Brasília, 1998. 1 de julho. 20p.

DI MARCO, O.N. Crecimiento y respuesta animal. Balcarce: Asoc. Arg. de Prod. Animal, 1993. 129p.

EUCLIDES, V.P.B.; RAFFI, A.S.; COSTA, P.F. et al. Eficiências biológica e econômica de bovinos em terminação alimentados com dieta suplementar em pastagem de capim-marandu. Pesqui. Agropecu. Bras., v.44, p.1536-1544, 2009.
FELÍCIO, P.E. Desdobramento da qualidade da carne bovina. Hig. Alimentar, v.12, p.16-22, 1998.

FIDELIS, H.A.; BONILHA, S.F.M.; TEDESCHI, L.O. et al. Residual feed intake, carcass traits and meat quality in Nellore cattle. Meat Sci., v.128, p.34-39, 2017.

GARCIA, J.; EUCLIDES, V.P.B.; ALCALDE, C.R. et al. Consumo, tempo de pastejo e desempenho de novilhos suplementados em pastos de Brachiaria decumbens, durante o período seco. Semin. Cienc. Agrar., v.35, p.20952106, 2014.

HONIKEL, K.O. Reference methods for the assessment of physical characteristics of meat. Meat Sci. v.49, p.447-457, 1998.

LI, C.; ZHOU, G.; XU, X.; ZHANG, J. et al. Effects of marbling on meat quality characteristics and intramuscular connective tissue of beef Longissimus muscle. AsianAustralas. J. Anim. Sci. v.19, p.1719-1808, 2006.

MUCHENJEA, V.; DZAMA, B.K.; CHIMONYO, M. et al. Some biochemical aspects pertaining to beef eating quality and consumer health: a review. Food Chem. v.112, p.279-289, 2009.

NUTRIENT requirements of beef cattle. 7.ed. Washington: National Academy 1996 242p.

OFFICIAL methods of analysis, 15.ed. Arlington, Virginia: AOAC, 1990.

OFFICIAL United States Standards for Grades of Carcass Beef. Washington: USDA. 1997.

REIS, R.A.; NUSSIO, L.G.; COAN, R.M. et al. Adequação ao uso de alimentos volumosos: Custos de produção e desempenho comparativo. In: COAN, R.M.; REIS, R.A. (Orgs.). Confinamento: gestão técnica e econômica. Jaboticabal: [SBA], 2006. p.113-136.

RESEARCH guidelines for cookery sensory and instrumental tenderness measurement of fresh meat. Chicago: AMSA, 1995. 48p.

ROBINSON, D.L.; FERGUSON, D.M.; ODDY, V.H. et al. Genetic and environmental influences on beef tenderness. Aust. J. Exp. Agric. v.41. p.997-1003, 2001. 
RODAS-GONZÁLEZ, A.; HUERTA-LEIDENZ, N.; JEREZ-TIMAURE, N. et al. Establishing tenderness thresholds of Venezuelan beef steaks using consumer. Meat Sci., v.83. p.218-223, 2009.

SAS user's guide statistics, version 9.2. Cary: SAS, 2008.

SILVA, D.J.; QUEIROZ, A.C. Análise de alimentos: métodos químicos e biológicos. Viçosa, MG: Universidade Federal de Viçosa, 2002. 235p.

SOLLENBERGER, L.E.; CHERNEY, D.J.R. Evaluating forage production and quality. In: BARNES, R.F.; MILLER, D.A.; NELSON, C.J. (Eds.). Forages: the science of grassland agriculture. Lowa: State University Press, 1995. p.97-110.
SOLLENBERGER, L.E.; MOORE, J.E.; ALLEN, V.G. et al. Reporting forage allowance in grazing experiments. Crop Sci. v.45, p.896900, 2005.

VAN SOEST, P.J. Nutritional ecology of the ruminant. 2.ed. Ithaca: Cornell University, 1994. 476p.

VAZ, F.N.; RESTLE, J.; ARBOITE, M.Z. et al. Características de carcaça e da carne de novilhos e novilhas braford superjovens, terminados com suplementação em pastagem cultivada. Cienc. Anim. Bras. v.11, p.42-52, 2010. 